\title{
The National Support Centre for Agriculture as the Trustee of Agricultural Property Stock of the State Treasury in Poland
}

\begin{abstract}
On 1 September 2017, the National Support Centre for Agriculture was established and appointed to serve as the Trustee of the Agricultural Property Stock of the State Treasury in Poland. This study profiles the legal relationship of the trust and points out its specifics in reference to stateowned agricultural property. The article includes an evaluation of the assumed legal solutions for the National Support Centre for Agriculture and compares them to the operations of the abolished Agricultural Property Agency.
\end{abstract}

Key words: National Support Centre for Agriculture, agricultural property, State Treasury, agricultural real estate

JEL Classification: Q18

\section{Introduction}

In 2017, the Polish legislature ${ }^{2}$ decided to introduce organisational changes to agricultural ownership by the state. Pursuant to art. 45 of the law establishing KOWR from 31 August 2017, the Agricultural Property Agency $^{3}$ and the Agricultural Market Agency were abolished and replaced with the National Support Centre for Agriculture ${ }^{4}$ (KOWR) as of 1 September 2017. Some responsibilities of the Agricultural Market Agency were also transferred to the Agency for Restructuring and Modernisation of Agriculture. Pursuant to art. 9 section 1 of the law on KOWR, the National Support Centre for Agriculture handles assignments resulting from state policy, specifically in the scope of the implementation and application of instruments of support for agriculture, active agricultural policy, and development of rural regions.

KOWR serves as a new organisational structure to handle tasks associated with managing the agricultural property of the State Treasury that were previously entrusted to ANR, including by using effective legal instruments, as well as certain assignments of the also-abolished Agricultural Market Agency. However, the changes that established the objectives of KOWR's operations and affect its management of state-owned agricultural property are marginal. Meanwhile, the ratio legis of the law establishing KOWR was based on optimisation of agricultural agencies' operations.

\footnotetext{
${ }^{1}$ PhD, Department of Finance, Faculty of Economic Sciences WULS-SGGW, address: ul. Nowoursynowska 166, 02-787 Warszawa, e-mail: przemyslaw_litwiniuk@sggw.pl; https://orcid.org/0000-0003-2099-157X

${ }^{2}$ Specifically, through the law on the National Support Centre for Agriculture of 10 February 2017 (Journal of Laws of 2017 item 623, hereinafter: "law on KOWR") and the law on provisions establishing the National Support Centre of 10 February 2017 (Journal of Laws of 2017 item 624, hereinafter: "law establishing KOWR").

${ }^{3}$ Hereinafter: "ANR".

${ }^{4}$ Hereinafter: "KOWR".
} 
Pursuant to art. 46 section 1 of the law establishing KOWR, the National Support Centre for Agriculture became the universal successor to ANR, which was abolished on 31 August 2017. ANR, including its assets, became the property of KOWR. Furthermore, as specified further in art. 46 of said law, KOWR also acquired the rights and responsibilities resulting from art. 5 of the law ${ }^{5}$ on the management of State Treasury agricultural property of 19 October 1991, which designated KOWR as the trustee of the Agricultural Property Stock of the State Treasury ${ }^{6}$.

Concerning the legal nature of the National Support Centre for Agriculture, it should be noted that it was patterned after the abolished agricultural state agencies. It is a state legal person with the status of executive agency, as discussed in art. 18 and the following articles of the law on public finance of 27 August $2009^{7}$.

\section{Trust relationship}

The concept of "property management" appears in the body of Polish normative laws regulating the management and administration of public property and covers the general real and legal activity associated with the management and administration of said property. In reference to the agricultural property of the State Treasury which constitutes the Agricultural Property Stock of the State Treasury, this concept is associated with the execution of the responsibilities of ownership and other rights entitled to the State Treasury by the entity established for this purpose. These responsibilities are performed as part of normative activity specified in the law on management. The legislative changes made in association with establishing the National Support Centre for Agriculture were produced by the re-evaluation of the main principles of Polish agricultural policy with regards to the functions and performance of the state's agricultural property stock. The current legal status for management of state-owned agricultural property results from the evaluation of normative solutions within the organisational and legal area, effectively establishing a new aspect of the legal relationship between the State Treasury, as the owner of the WRSP stock, and the Trustee, who is performing the responsibilities specified in this law.

The normative source of the trust relationship for WRSP stock is referred to in art. 5 of the law on management. The specifics of this relationship result mainly from the nature of the property relationship in the state's structure; both the State Treasury and other legal state entities are entities associated with a state organisation executing the property-related interests of the state (Doliwa, 2000b, p. 85).

The trust relationship established pursuant to art. 5 of the law on management creates a situation where the entity authorised to execute specific responsibilities under its power is not acting alone because said entity does not have any assignments towards the property. It acts on its own behalf in third party relations, but performs activity on behalf of the State Treasury when executing responsibilities and tasks assigned by the legislature as outlined previously in art. 6 of the law on management and currently in art. 9 of the law on KOWR (Doliwa, 2000a, p. 131). The specifics of the aforementioned relationship are such that the

\footnotetext{
5 Journal of Laws of 2016 item 1491 as amended, hereinafter: "law on management".

${ }^{6}$ Hereinafter: "WRSP stock".

${ }^{7}$ Journal of Laws of 2017 item 2077 as amended.
} 
will of the State Treasury - as the possessor of ownership rights who wants to see the responsibilities executed - and the will of the trustee who assumes those responsibilities are supported by the will of the legislature. This is currently expressed in art. 9 of the law on KOWR, which allows to define the function of WRSP stock assigned by the Polish legislature in the state's agricultural policy.

\section{Suspension law}

The law suspending the sale of Agricultural Property Stock of the State Treasury and amending certain other laws of 14 April $2016^{8}$ took effect on 30 April 2016, i.e., on the eve of expiration of the transitional period, during which there were purchases of agricultural and forest property located in Poland by citizens of European Economic Area states, as subject to restrictions imposed by the law on property purchased by foreigners of 24 March 1920. In principle, the law in question was supposed to ease concerns about the escalating number of purchases of state-owned agricultural land in Poland by citizens of other European Union states and give Polish farmers 5 years to improve their economic competitiveness.

The name of the law indicates that the matter of restricting sales of state-owned land should have a capital meaning to its structure. However, the substantive provisions referring to the eponymous issue comprise just two significant clauses. Under the power of art. 1, the legislature suspended the sales of WRSP stock for 5 years following the law's effective date (i.e., until 30 April 2021). This automatically turned leasing into the leading method for the development of treasury-owned land. It could seem that a reformulation of the state's agriculture property would be important as this would require appropriate interference in the law on management, but, as amended, art. 24 of the law in question defines the privatisation activity of the trustee of WRSP stock as equivalent to restructuring activity'.

The trading restrictions introduced by the suspension law concern only nonagricultural WRSP stock property. Art. 2 of said law defines that as property planned for non-agricultural purposes, i.e. those specified in development plans, development studies and instructions, and the final decision determining the development of space and building conditions. The specific properties deemed non-agricultural were designated by the legislature as being planned for establishments like technology parks, industrial parks, and business and logistics centres.

Another factor excluding application of the suspension law is the two-hectare area standard. Property of an area smaller than 2 ha may be sold under the previous regulations. Meanwhile, KOWR's sale of property exceeding 2 ha depends on the approval of the Minister of Agriculture and Rural Development (art. 2 section 2 of the suspension law). The approval for sale of WRSP stock property is granted upon the request of the KOWR Director General conditional upon social and economic factors. However, the aforementioned rationing of WRSP stock agricultural property may raise serious concerns. First of all, restrictions for trading stateowned land specified in this manner may lead to arbitrary settlements between the participating bodies. The adequacy of the legislature's use of the general clause structure and the social and economic factors considered by the minister in determining access to public property, which

\footnotetext{
${ }^{8}$ Journal of Laws of 2018 item 869 as amended, hereinafter: "suspension law".

${ }^{9}$ See art. 6 point 6 of the suspension law.
} 
unquestionably includes WRSP stock property, must be called into question. In principle, general clauses cover a group of hard-to-define terms, which makes the interpretation of the provisions therein very arbitrary. For this reason, in order to keep the Ministry of Agriculture and Rural Development, in the execution of its authority regarding access to WRSP stock property, from being exposed to the charge of violating the rule of equality before the law expressed in art. 32 of the Polish Constitution, the legislature should have reserved the option for the ministry to establish executive regulations covering the detailed conditions and mode of approval for purchases of WRSP stock agricultural property.

\section{Amendments to the management law}

In reference to amendments to provisions of the material law standardising sales of state-owned land in the law on management, it should be noted that the legislature decided to implement mechanisms that are, in principle, supposed to prevent acquisition of stateowned agricultural property by individuals who cannot guarantee the its production potential will be used appropriately and thus to prevent acquisition of said property for purposes of speculation. This is supposed to enhance the agricultural use of WRSP stock property, and primarily enforce its proper distribution as a non-reproducible public good ${ }^{10}$.

The addition of section $3 \mathrm{ba}^{11}$ to art. 29 of said law excludes three categories of people from participating in limited tenders for the sale of state-owned agricultural property. The first category covers those who have ever purchased WRSP stock property with a total area of at least 300 ha and have subsequently sold it. The next group covers people who sold property acquired from WRSP stock within 15 years of purchase or took a mortgage on it within this period, as well as people who filed false statements on the origin of funds used to purchase the property and those who have come to a preliminary agreement for sale of the property they planned to purchase from WRSP stock. The aforementioned exclusions are associated with restricting access to tenders from those who would trade agricultural property from the state to create or expand family holdings, i.e., in cases where the acquisition of agricultural property may be dictated by business rather than strictly agricultural purposes. The third category of people excluded from limited tenders includes people who held stock or shares in companies owning agricultural property on the date of the list's publication. This seems to be the most controversial exclusion, as it is hard to see this group benefiting from protection of family holdings or use of agricultural property for agricultural purposes.

The rationing trends of WRSP stock property trading include section 3bc, which was added through the amendment to the content of art. 29 of the law on management. It blocks access to limited tenders by people with public-legal arrears and people currently or previously administering WRSP stock property with no legal right and failing to leave said property despite being summoned to do so.

According to the above, the suspension law re-evaluated the fundamental objectives of the trustee's activity. The trustee is no longer the entity whose primary objective is the mission of privatisation. It should be noted that the annual sales of state-owned land oscillated between

\footnotetext{
${ }^{10}$ See justification of the suspension law bill

${ }^{11}$ See art. 6 point 8 of the suspension law.
} 
around 100 000-120 000 ha between 2008 and 2015. Since 1996, it was the dominant way of distributing WRSP stock property ${ }^{12}$. In 2016, with the introduction of the suspension law, the privatisation activity of ANR and subsequently of KOWR considerably dropped. In 2017, sales amounted to only $4,100 \mathrm{ha}^{13}$. This situation led to the automatic reorientation of WRSP stock land towards leasing; this method of state-owned land distribution accounted for almost 60 thousand ha in 2016 and 52 thousand ha in $2017^{14}$.

The aforementioned amendment added provisions establishing the criteria for written limited tenders, which in principle represent the most effective form of support for family holdings. The decision to standardise this special form of tendering seems to be right, as ANR used to announce such tenders without clear legal grounds before the introduction of the suspension law, in response to the postulates of agricultural self-governing bodies.

The statutory establishment of the criteria of this method of distributing state-owned land is completely justified; in this way, written tenders are restricted by the qualified form of family holding support, which is distinguished by selecting the offer based on management criteria instead of economic criteria. Pursuant to art. 29 section 3 of the law on management, written limited tenders result in purchases of WRSP stock property at a price corresponding to the value of the property specified in the valuation survey. When the main form of WRSP stock property management is leasing, rent is not a graded element of the offer and is the same for all bidders. Instead, the decision elements of the given offers are, in accordance with art. 29 section 3 point 3 of the law on management: distance between the bidder's agricultural holding and the stock property up for sale, area of agricultural space acquired or leased from WRSP stock, and the intensiveness of animal production in the bidder's holding. Following the amendment to the suspension law, the organisation of such tenders in the aforementioned form requires a much more comprehensive bidder selection procedure than in common bid tenders, even in the limited procedural form. In this area particularly, entrusting the minister in charge of rural development to release executive regulations standardising the details of limited written tenders would be recommended. The lack of delegation in this area may have a negative effect on the certainty of legal transactions in the leasing of state-owned property because, under the current legal status, the organisation of these tenders is based exclusively upon the internal procedures of the trustee.

Irrespectively of the introduction of the aforementioned mechanisms, the amendment to the law on management also affected the content of ownership relations between the trustee managing WRSP stock and third parties. This change was in response to the legislature's attempts to restrict speculative land purchases and enforce the guarantee of their being used for agricultural purposes. This objective may be achieved thanks to the mandatory provisions specified in art. 29a section 1 of the law on management included in the agreement of sale of WRSP stock agricultural property. The provisions include mainly

\footnotetext{
${ }^{12}$ See Raport z działalności Agencji Nieruchomości Rolnych na Zasobie Własności Rolnej Skarbu Państwa w 2016r. (Report on the activities of the Agricultural Property Agency on the State Treasury Agricultural Property Resources in 2016), Warsaw 2017, p. 43, source: http://www.kowr.gov.pl/zasob/raporty-roczne-anr.

${ }^{13}$ See Sprawozdanie z działalności Krajowego Ośrodka Wsparcia Rolnictwa w 2017 roku (w tym Agencji Rynku Rolnego i Agencji Nieruchomości Rolnych w okresie od 1 stycznia do 31 sierpnia 2017 r.) (Report on the activities of the National Support Centre for Agriculture in 2017 (including Agricultural Market Agency and Agricultural Property Agency in the period from 1 January to 31 August 2017), p. 24, source: http://bip.kowr.gov.pl/

uploads/pliki/BDG/SPRAWOZDANIE\%20KOWR\%202017\%20OSTATECZNE\%20z\%20podpisem\%20DG.pdf.

${ }^{14}$ Ibid, p. 36.
} 
the purchaser's commitment to refrain from transferring ownership of the property and to use the property for agricultural purpose for 15 years following the date of purchase and for natural persons - to conduct the agricultural activity personally. Another obligatory element of the agreements transferring ownership of WRSP stock agricultural property is the purchaser's commitment to refrain from mortgaging the acquired property. These obligations are secured with a sanction in form of a cash fine amounting to $40 \%$ of the property sale price, which the purchaser agrees to pay in the property acquisition agreement.

However, the legislature additionally provided for the possibility of selling or mortgaging the property acquired from WRSP stock before expiration of the 15-year period with the approval of KOWR ${ }^{15}$.

\section{New aspects of KOWR operations}

In designating KOWR as the entity managing the WRSP stock property, the law should also make mention of the assignments to be performed by it. Art. 9 section 2 of the law on KOWR, which defines the catalogue of assignments associated with the management of WRSP stock property, is mostly a copy of the repealed art. 6 of the law on management ${ }^{16}$, whereas the responsibilities around initiation of agricultural machinery work by private agricultural holdings on State Treasury land (specified in the repealed art. 6 section 1 point 7 of the law on management), which were previously assigned to ANR, are regulated in a different manner. The content of art. 9 section 2 of the law on KOWR gives it responsibility for initiation of agricultural machinery work (point 7) and support for organisation of agricultural holdings on State Treasury land (point 8). The reorientation of the previous assignments of ANR specified this way means that KOWR can become an active participant of the structural policy and that its activity in this area will not be limited to WRSP stock but will also cover private land ${ }^{17}$.

While the aforementioned change can be seen as positive, it is difficult to evaluate the establishment of KOWR as the entity responsible for supporting the organisation of agricultural holdings on State Treasury land without having specified that it applies to private holdings. This may entail the return of treasury holdings being established on the property of WRSP stock (see Prutis, 2000, p.51). The activity of KOWR in this area may weaken its role as being primarily responsible for the development and improvement of the territorial structure of family holdings, i.e., individual holdings.

Considering the past critical opinions towards ANR for its structural heaviness (Czechowski, 2008, p. 84) and analysing the effective legal regulations concerning the organisation of KOWR as a trustee of the State Treasury managing WRSP stock property, the legislature's attempts at making the entity's structure more like an office can be seen as alarming. The currently effective art. 4 section 1 of the law on KOWR establishes that the

\footnotetext{
${ }^{15}$ See art. 29a section 4 of the law on management.

${ }^{16}$ See art. 8 point 5 of the law establishing KOWR.

${ }^{17}$ To be effective, this mechanism requires amendment to the law on land merger and exchange of 26 March 1982 (consolidated text, Journal of Laws of 2014 item 700) in order for KOWR to have greater initiative in the mechanisms laid out by said law as the trustee of WRSP stock property.
} 
entity is coordinated by the Director General, a nomenclature borrowed from civil service ${ }^{18}$. It seems that the aforementioned name change is not coincidental and that it is an attempt to emphasise the solely executive function of the Director General as an authority of KOWR towards the superior Minister of Agriculture and Rural Development. This is mostly confirmed in the content of art. 10 of the law on KOWR, pursuant to which the entity can perform assignments entrusted by the public finance entity other than those specified in art. 9 section 2 with prior approval of the Minister of Agriculture and Rural Development.

\section{Conclusion}

The legal regulation of the National Support Centre for Agriculture presented above supports the conclusion that the establishment of this entity results from the evolution of legal solutions standardising management of WRSP stock property. Furthermore, KOWR at least temporarily dissociates from the previous role of ANR as the entity privatising the agricultural property of the State Treasury and emphasises the restructuring function supplemented by elements of agricultural property trading control aimed at strengthening family holdings (Czechowski, 2008, p. 80). This combination of control and trust functions raises legitimate controversy. The main accusation is that this situation has had an adverse effect on the privatisation of WRSP stock property (Lichorowicz, 2000, p. 388). This process is slowed down by the restriction of sales of WRSP stock land and the establishment of KOWR, which is reflected in the aforementioned numerical data concerning sales of state-owned land. The regulations of the suspension law standardising this matter demonstrate excessive interference by the legislature in the trust relationship. The effectiveness of rationing WRSP stock property trading in the form established by the provisions of the suspension law should be called into question. It primarily raises questions about inconsistency in the activity of the legislature, as it introduces numerous restrictions in rationing sales of state-owned land meant to direct the trade of state-owned land in a way that would ensure that the purchaser takes advantage of its production value and reduce speculation; however, it has simultaneously prevented sales of WRSP stock property, leading to leasing as the most efficient distribution method.

At this stage, it is not yet possible to assess the effectiveness of reorganisation of the structures responsible for management of the State Treasury's agricultural property. Such an assessment requires more time. Nevertheless, it can be assumed that the concentration of the competencies associated with both executing trust assignments and other assignments of the Agricultural Market Agency associated with the operations of agricultural and food markets as well as the simultaneous option of delegating the responsibilities of the payment agency to this entity will grow the organisational structure of KOWR. This situation will restrict the entity's productive capacity, which may have an exceptionally negative impact on the performance of the trust functions that are the core of its operations.

\footnotetext{
${ }^{18}$ See civil service law of 21 November 2008 (consolidated text, Journal of Laws of 2017 item 1889).
} 


\section{Bibliography}

Czechowski, P. (2008). Agencja Nieruchomości Rolnych - restrukturyzacja czy likwidacja? (Agricultural Property Agency - restructure or liquidation?). Przeglad Prawa Rolnego, 2(4), 75-97.

Doliwa, A. (2000a). Jeszcze w sprawie powierniczego statusu Agencji Własności Rolnej Skarbu Państwa (More on the trust nature of the responsibilities of the Agricultural Property Agency of the State Treasury). Rejent, 2(106), 124-134.

Doliwa, A. (2000b). Powierniczy charakter uprawnień Agencji Własności Rolnej Skarbu Państwa (The trust nature of the responsibilities of the Agricultural Property Agency of the State Treasury). Studia Iuridica Agraria 1, 75-98.

Lichorowicz, A. (2004). Instrumenty oddziaływania na strukturę gruntową Polski w ustawie z dnia 17 kwietnia 2003 r. o kształtowaniu ustroju rolnego (Instruments affecting the land structure of Poland in the law on developing the agricultural system of 17 April 2003). Kwartalnik Prawa Prywatnego, 13(2), 387-434.

Prutis, S. (2000). Kierunki zmian modelowych restrukturyzacji i prywatyzacji rolnictwa polskiego rolnictwa (Directions of changes in model restructuring and privatisation of Polish agriculture). Studia Iuridica Agraria, 1, 47-64.

For citation:

Litwiniuk P. (2018). The National Support Centre for Agriculture as the Trustee of Agricultural Property Stock of the State Treasury in Poland. Problems of World Agriculture, 18(3), 208-215; DOI: 10.22630/PRS.2018.18.3.79 